\title{
DIFFERENT SHADES OF GREEN: ENVIRONMENT UNCERTAINTY AND THE STRATEGIES OF HYBRID ORGANIZATIONS
}

\author{
Juan Almandoz, Matthew Lee and \\ Christopher Marquis
}

\begin{abstract}
How does environmental uncertainty affect the process of starting new hybrid organizations? Our comparative analysis of the formation of two "green" banks - with hybrid goals linked to banking and environmental logics - reveals that shifts in their strategic orientations resulted from attempts to align uncertain and changing resource environments with the composition and goals of the organizations' top leadership. While the initial idea and goals of the founders were similar, the organizations they established ended up with divergent strategic orientations and senior leadership groups.
\end{abstract}

Keywords: Institutional uncertainty; hybrid organizations; complexity; strategic orientation; institutional logics, resource acquisition

\footnotetext{
Emergence

Research in the Sociology of Organizations, Volume 50, 31-67

Copyright (C) 2017 by Emerald Publishing Limited

All rights of reproduction in any form reserved

ISSN: 0733-558X/doi:10.1108/S0733-558X20170000050002
} 


\section{INTRODUCTION}

How are the strategies of new organizations shaped by the institutional environments in which they emerge? Institutions grant legitimacy to organizations that follow established organizational forms, thereby facilitating access to resources needed to support their strategies (Aldrich \& Fiol, 1994; Suchman, 1995). New organizations' strategies are also shaped by local institutional logics that provide order and meaning to organizational activities (Friedland, \& Alford, 1991; Thornton, Ocasio, \& Lounsbury, 2012), and by other market, regulative, social, and cultural factors (Marquis \& Battilana, 2009). These diverse pressures provide a new organization with templates for action, generally resulting in conformity with established organizational forms present in their institutional environments (DiMaggio \& Powell, 1983).

Institutions thus benefit new organizations by facilitating their alignment with established organizational fields. However, these same institutional pressures may be antagonistic to organizations attempting to engage in innovative entrepreneurship that diverges from institutional norms. Such organizations frequently adopt innovative hybrid models of organizing that require new combinations of cultural and material resources, and thus are exposed to disparate and changing institutional pressures (Kraatz \& Block, 2008). Previous research has noted that such organizations tend to operate at the fringes of stable resource niches, where access to resources is risky and unpredictable (Haveman \& Rao, 2006). By pursuing strategies that require diverse resources, these organizations open themselves to multiple, variable, and discordant demands, to which established templates provide no viable response (Greenwood, Raynard, Kodeih, Micelotta, \& Lounsbury, 2011).

Innovative hybrid organizations thus confront a particular type of environmental uncertainty associated with changing and competing institutional pressures. Previous research on the emergence of organizations often assumes that the local resource environment occupied by a given organization is relatively well-defined and consistent. However, environmental instability and ambiguity is an integral aspect of the organizational founding process, particularly for organizations that deviate from established organizational forms (Aldrich \& Fiol, 1994; Suchman, 1995). Such organizations are prone to search across discontinuous resource environments before settling on a stable organizational strategy (Battilana \& Dorado, 2010), and thus face uncertainty in the very definition and scope of the resource environment they occupy. The environmental fluidity faced by these new ventures resembles the conceptualization by entrepreneurship scholars of uncertainty as an "unknown unknown" which defies evaluation - distinct from measurable uncertainty 
(Knight, 1921; McMullen \& Shepherd, 2006) - because the institutional environment with which the organization must contend is ambiguous ex ante. If such environmental uncertainty is an essential feature of new organizations that deviate from established forms, its consequences are important to understand, because environmental influences at the time of founding are likely to persist over time (Marquis \& Tilcsik, 2013; Stinchcombe, 1965). Thus, we ask: how does uncertainty in the environment of a divergent, innovative organization influence its strategic orientation?

To address this question, we explore the co-emergent process of an organization's strategic orientation and the internal representation of institutions among its senior leadership. Senior leaders profoundly influence the fates of organizations through their consideration and selection of organizational strategies (Finkelstein, Hambrick, \& Cannella, 2009), as well as by facilitating relationships with their organizations' external environments. Organizations typically select leaders that align with their external environments, and thereby represent external pressures in decision-making. For new, divergent organizations, however, this selection process is subject to environmental uncertainty. As new organizations emerge, 'leaders of these organizations may thus be selected according to multiple and uncertain external pressures (Greve, 2008), which will influence those leaders' future decisions. Since each decision of those senior leaders is influenced by preceding choices, the sequence in which different parts of the environment receive the leaders' attention are likely to have important consequences for the organizations' ultimate strategic orientation (David, 1994).

We examine these issues through a comparative case study of the creation of two of the first "green banks" in the United States. Both were founded in the first decade after the year 2000, one in a Western state and one in a Southern state. The goals of the founders in creating these novel organizations were both to make money and to support the well-being of the natural environment. These goals were aligned, respectively, with standards and practices taken from the banking sector and also from the field of "green" environmental sustainability organizations. Both green banks were thus founded as hybrid organizations, influenced simultaneously by multiple resource environments that imposed conflicting standards of legitimacy and behavior (Battilana \& Lee, 2014; Besharov \& Smith, 2014; Jay, 2013; Thornton et al., 2012). At the time of their founding, green banks were a nascent type of organization affected by uncertainty in its essential goals and activities and thus in the definition of the relevant resource environment. The two green banks we studied thus provided a suitable setting to explore the implications of environmental uncertainty for innovative hybrid organizations. 
The geographical locations of the two banks we studied varied significantly in their resource environments. This feature enabled us to observe variation in how the banks' strategies responded to differing environmental changes. Establishing the new organization was difficult in both locations, but the resource environment was especially challenging in the Southern state. For the purposes of our study, the banking sector also has the attractive feature the process of starting new banks follows a clear, well-established sequence of events whereby specific parts of the environment (investors, regulators, customers, etc.) become especially relevant (Almandoz, 2012). This feature enabled the comparison between cases at similar stages in each bank's development. The time period examined, from 2005 to 2012 (extending beyond the founding period), offered a good opportunity to observe the implications of uncertainty stemming from the 2008 economic crisis, some of which affected industries with which the banks were directly involved. Our analysis focused on the process and mechanisms by which a strategy was defined over time to achieve those goals.

This study contributes to the literature on institutions and entrepreneurship by explicitly theorizing the process by which innovative hybrid organizations define their strategic orientations in the face of uncertainty in their local resource environments. First, our findings suggest that uncertainty plays a key and nuanced role in entrepreneurial founding as entrepreneurs search for resources and adapt their strategic orientation to the local availability of suitable resources. Second, we contribute to research on internal representation of institutional logics within hybrid organizations (Pache \& Santos, 2010) by exploring how new organizations in complex environments (Kraatz \& Block, 2008) incorporate multiple field-level logics in the composition of their strategic decision-making teams. Our findings suggest that, especially among innovative hybrid organizations, the internal representation of competing logics may not be an "a priori" factor driving the process of organizational creation but may be endogenous to this process and consequential to its outcome.

\section{THEORETICAL CONTEXT}

\section{Institutional Uncertainty and Entrepreneurship}

Abundant previous research has addressed how institutional influences in local environments affect organizational forms and practices (DiMaggio \& 
Powell, 1983; Meyer \& Rowan, 1977; see also Marquis \& Battilana, 2009). The presence of strong institutional norms can enable new enterprises to establish their legitimacy by conforming to established conventions and thus to acquire resources. By contrast, failure to conform to established conventions can result in an "illegitimacy discount" (Zuckerman, 1999) that complicates the acquisition of resources, thereby aggravating the legitimacy struggles that all new organizations face (Stinchcombe, 1965). Alignment with institutional expectations is thus critically important for the viability of new organizations.

Given the importance of institutional environments, uncertainty would be expected to weigh heavily upon entrepreneurial outcomes. Yet to the degree that researchers have explored changing environments over time (Thornton, 2004), studies have focused on drawing linkages between gradual changes in the institutional environment and population-level founding rates. An advantage of this approach is that in such settings, the link between institutional change and entrepreneurial opportunities can be more easily established (see Tolbert, David, \& Sine, 2011 for a review of the literature on how institutions shape entrepreneurial choices). However, research has yet to fully explore how entrepreneurial organizations develop their strategic directions contemporaneously with the unfolding of their institutional environments in real time, and the results of these processes for these organizations' strategic orientations. Uncertainty is likely to be a critical factor for new hybrid organizations that are outside of established or conventional forms.

Previous research has conceptualized multiple types of uncertainty in organizational environments. For instance, Milliken (1987) subdivided the concept of environment uncertainty into three types: uncertainty about the state of the environment - addressing for instance the likelihood of experiencing a crisis or a drop in demand (Adner, 2002); uncertainty about the degree to which environment changes will have an effect on the organization (for instance a crisis drying up resource pools for the organization) (Duncan, 1972; Lawrence \& Lorsch, 1967; Tushman \& Anderson, 1986); and, finally, uncertainty about organizational response options and about the likely consequences of those options (Conrath, 1967; Duncan, 1972; Taylor, 1984).

Innovative hybrid organizations are likely to experience each of these types of uncertainty to varying degrees. Hybrid organizations that operate at the fringes of multiple institutional environments face uncertainty related to the states of those multiple environments, how they will affect the organization, and how the hybrid organization might respond. In some respects, 
the institutional plurality of these organizations' environments, as the organizations are exposed to a greater diversity of sources of risk. However, hybrids may also have broader options to respond to uncertainty in one institutional domain, including shifting their strategic orientation to align with another institutional domain. In such circumstances, shifting the strategic orientation of the organization may be a way to deal with environmental uncertainty.

Previous research has argued that institutional change - for instance, the historical transition of the banking industry from a community to an efficiency logic - can increase environmental uncertainty and thus affect the strategies of entrepreneurs. Marquis and Lounsbury (2007) found that as larger banks acquired community banks - imposing an efficiency logic in the local banking sector - banking entrepreneurs found support to start new banks that embraced a community logic. Institutional changes can give rise to new organizational forms by making resources available to entrepreneurs who are skillful at the art of institutional bricolage, defined as, "importing and exporting cultural symbols and practices from one institutional order to another" (Thornton \& Ocasio, 2008, p. 115), or at mobilizing actors invested in the success of a particular institutionalization project (DiMaggio, 1991).

One of the most central ways that emerging organizations manage uncertainty is through the composition of their founding board of directors or strategic decision-making team (Boyd, 1990). For example, scholars have discovered that when environments are uncertain, more interlocks among board members are expected to secure access to information from multiple sources (Boyd, 1990; Pfeffer \& Salancik, 1978). New organizations in those uncertain environments are likely to have more hierarchy and more focus on discipline and authority (Pfeffer \& Leblebici, 1973) and they may actively manage their stakeholders (Ansoff, 1965; Emshoff \& Freeman, 1981; Mason \& Mitroff, 1981) to energize and channel specific interest groups that are critical to the organization's functioning. By creating a "negotiated environment" (Cyert \& March, 1963), these organizations can guard against external threats that might have de-legitimating or destabilizing effects.

\section{Senior Leadership Teams in Hybrid Organizations}

Senior leaders of hybrid organizations face the distinctive challenge of skillfully managing the expectations and demands of diverse organizational 
stakeholders (Johnson, 2007). Organizations attempting to create new organizational forms assert a set of core features that differs from that of existing forms (Navis \& Glynn, 2010), and thus face the challenge of incompatibility with the institutional rules dominant in existing fields (Aldrich \& Fiol, 1994). While founders may possess clear visions for their organizations, the realization of their plans is conditional on the approval of powerful actors in the new organization's environment. To gain this approval, senior leaders of hybrid organizations must successfully develop resource exchange relationships with key stakeholders - such as suppliers, distributors, financiers, and customers - who themselves are typically embedded in the institutional logics from which the new venture diverges (Loewenstein, Ocasio, \& Jones, 2012; Pache \& Santos, 2010; Thornton et al., 2012).

As senior leadership is responsible for the acquisition of all other organizational resources, the senior leadership team is arguably the most essential resource acquired by the emergent organization. Hybrid organizations recruit senior leaders whose identities, values, and assumptions correspond to the dominant logics of powerful stakeholders (Almandoz, 2012, 2014; Pache \& Santos, 2010). Studies of organizations that defy dominant organizational forms increasingly emphasize the extent to which they navigate multiple logics in the acquisition, and retention, of key resources. Senior leadership teams in which multiple logics are represented enable such organizations to simultaneously address competing standards of legitimacy and behavior (Ashforth \& Reingen, 2014; Battilana \& Lee, 2014; Jay, 2013; Pache \& Santos, 2010).

As a result, hybrid organizations face external pressures to compose a strategic decision-making team that represents the dominant logics in their environments (Almandoz, 2012, 2014; Pache \& Santos, 2010). These pressures are likely to have significant effects in hybrid organizations, which lack the enabling effects of conformity to established institutional norms. Once selected, senior leaders represent the logics they carry within the organization, and thus act as a channel for institutional influence on decisionmaking. The presence and distribution of this representation is likely to shape the organization's strategic direction (Besharov \& Smith, 2014; Pache \& Santos, 2010).

\section{Strategic Orientation}

Organizations can respond to conflicting institutional demands in multiple ways. Pache and Santos (2010) mapped a range of possible organizational responses - including strategies such as compromise, avoidance, 
defiance, and manipulation - depending in part on the degree to which the multiple demands are internally represented within the organization, and on whether the conflict among logics is with respect to means or ends. While the distinction between means and ends may not always be obvious, and the two may in fact overlap (Meyer \& Rowan, 1977; Pache \& Santos, 2010) in environments influenced by multiple logics, there may be variations over time, and across organizations, in how dominant one institutional logic is with respect to the other as, for example, in the degree to which the goals inherent to the banking logic, such as profitability or growth, take priority over social considerations grounded in a green logic.

The strategic orientation of a hybrid organization can be defined as the degree to which the goals of one institutional logic are dominant over the goals of another. In principle, such orientation is likely to be revealed not when the goals derived from both logics are compatible and synergistic but when tradeoffs are encountered and choices are made, including the choice to invite to the board of directors a key resource provider who could conceivably weigh in later on the direction of the organization. An organization's strategic orientation in response to competing institutional demands (Delmas \& Toffel, 2008) is expressed in policies, strategic statements, and business plans and is interpreted and enacted by various organizational members promoting specific values, goals, and interests (Greenwood \& Hinings, 1996).

\section{CONTEXT OF THE STUDY}

\section{The Rise of a Green Institutional Logic}

The creation of the first green banks in the United States followed a period of dramatic growth in public concern about the state of the natural environment. In 2005, Al Gore's documentary on global warming, "An Inconvenient Truth," attracted widespread media attention and was instrumental in his later being awarded, with others, the Nobel Peace Prize. The year 2005 was also the year that the Kyoto Protocol, an international treaty setting obligations on countries to reduce emissions of greenhouse gases, entered into force. Geopolitical instability, particularly in the Middle East, had dramatically increased oil prices, causing investor and entrepreneur attention to shift toward renewable sources of energy. All these events contributed, in many fields, to the emergence of a green 
logic organized around products and services related to sustainability and renewable energy. For instance, growing trends in the construction and food industries favored green products, such as green buildings and organic-food products. According to a 2005 study of the National Association of Home Builders, 90 percent of U.S. home-builders were using "green" ideas. The organic-food industry had reached $\$ 30$ billion globally in 2005, and Whole Foods Supermarkets, the best-known retail firm in this sector, increased sales by 23 percent to $\$ 3.9$ billion in 2005 . Importing a green logic into banking was part of a broader Socially Responsible Investment (SRI) trend. According to a 2005 report, SRI assets in USA grew from $\$ 639$ billion in 1995 to $\$ 2.29$ trillion in 2005 , encompassing then nearly 10 percent of all assets under professional management. In Europe, banks including Triodos and Credit Agricole had adopted a green mission, but there was still no such precedent among for-profit banks in the United States.

A banking institutional logic in the context of local banks (Almandoz, 2012, 2014; Marquis \& Lounsbury, 2007) defines the legitimate meanings, expectations, and practices that govern this setting. In the context of new banks, this banking logic implies a relationship-centered service and reliance on the social and business networks of founding and management teams for referrals to investor capital, deposits and loans. This banking logic also involves rapid growth, a profit expectation, and an investment motivation because to some degree all new banks are "built to sell" - that is, started as investments (Almandoz, 2012, 2014).

Green banks sought to combine the green and banking logics in order to establish and legitimate a new organizational form. Because these organizations would depend on resources motivated by both logics, but would diverge substantially from both, such a combination risked legitimacy challenges and conflict between their respective rules and expectations. Decision-making teams in these green banks would need to both be attentive to pressures from their local banking environments and consistent with a green strategic orientation, however defined.

\section{METHODS}

\section{Data Collection}

One of the authors has previously conducted extensive research on traditional bank founding teams, collecting 76 interviews from CEOs, directors, 
bank employees, consultants, and regulators. This prior research provided an in-depth perspective on the bank founding experience, which illuminated the context of the founding of the two green banks. The similarity of each founding team's vision for building a green bank was especially clear in that wider context. Two of the coauthors were involved in visits to these two green banks and collected a total of 33 additional interviews, developing two teaching cases in the process. We first approached and interviewed the CEOs of both organizations, who were subsequently instrumental in facilitating broad access to board directors, bank executives, owners, clients, lawyers, and regulators. The structure of each interview followed a semi-structured interview protocol (Strauss \& Corbin, 1998). The preliminary questions addressed the idea of starting a green bank, the formation of the founding team, challenges in opening, evolution of the bank's green strategy, how the interview participant became involved with the bank, and how the green strategic orientation was received in the local area. Interviews ranged from 45 minutes to 2 hours, averaging around 1 hour. Almost all interviews were audiotaped and transcribed. The numbers of interviews by organization level are summarized in Table 1.

To supplement these interviews, we collected and analyzed extensive archival data, including documents presented by the bank to investors and other stakeholders, press releases, media coverage, web sites of both organizations, documents submitted to regulators for bank charter approval (specifying the business plan of the bank and the objectives and qualifications of founders and bank managers) and documents issued by regulators regarding the banks. Finally, we also analyzed bank portfolio and performance data.

Table 1. Interview Summary.

\begin{tabular}{lcc}
\hline & GREENWEST & GREENSOUTH \\
\hline CEO & 4 & 5 \\
Other directors & 2 & 6 \\
Clients & 1 & 3 \\
Bankers & 9 & 2 \\
Lawyer and consultant & & 1 \\
Total & 16 & 17 \\
\hline
\end{tabular}




\section{Data Analysis}

We approached the data with the goal of understanding how GREENWEST and GREENSOUTH arrived at very different strategic orientations despite the similar visions espoused by their founders at the time of founding. Several years after its founding, GREENWEST had adopted a policy of refusing to lend to companies with no commitment to sustainability. GREENSOUTH, by contrast, maintained a more open lending policy, channeling its green mission through a more visible, media-oriented strategy that emphasized its green headquarters building and its own sustainable practices, such as trying to minimize the use of paper. At first glance, differences in the receptiveness of each bank's geographic location to environmentally oriented ideas appeared to be decisive in the ultimate definition of their green strategies. However, further analysis revealed additional nuances that were important to explain the evolution of the two banks' strategic orientations.

The analysis prompted a dialogue (Eisenhardt, 1989; Ragin, 1994) between the data documenting influences on the green strategies and theories about internal representation of institutional logics in hybrid organizations and about how such organizations respond to institutional forces (Pache \& Santos, 2010, 2013). A first step in the analysis involved exploring the priorities at each stage and coding accordingly, using Atlas.ti, the sources of institutional pressures and the resulting influences on the bank's strategy. Initially, we focused on a small set of interviews (with the current CEOs of both organizations and the chairman of one) to analyze lines with open codes related to the "generation of the idea," the "mission," "assembling a founding team and board," dealing with "regulators," "investors," and "employees" as well as anticipating and responding to local market conditions.

For example, from one of the CEO's interviews the "generation of the idea" was coded as a "joint passion" for both business and the environment, a deeply-felt "opposition" to the right-wing banking culture, and a "conversation with a friend" while jogging at a forest. The stage involving "regulators" included codes on getting "expert help" from a prestigious bank lawyer and compiling a detailed "application and a business plan." Influences arising from interactions with regulators included "surprise" as regulators presented more difficulties than anticipated. As the CEO put it, "I thought wrongfully that with this sustainability initiative, I would get my charter easier." Another code arising from those interactions was "pushback" as regulators questioned the viability of the business plan and as 
they proposed additional scrutiny by making the bank a "niche" bank. As a result of that resistance, the "mission" veered toward the banking logic (becoming a traditional bank) and away from an integrated green mission. As the CEO admitted to saying to regulators, "If somebody comes in and they want to do a five-acre slash and burn development, we're still going to do it because we have shareholder value to maintain." A shift toward the banking logic was also evidenced by "resistance" from shareholders and a "lack of local interest" in sustainability because of the "crisis."

After the initial set of interviews was coded by one of the authors, we compared the two cases, searching for similarities and contrasts. At this stage, we noted that both banks' strategic orientations appeared to be driven by common mechanisms involving the initial idea and interactions with board members, regulators, investors, employees, and the local market. The strategic orientations of the two banks depended heavily on the composition of their senior leadership, whose selection and retention was determined by the demands of other external resource providers. Members of the banks' senior leadership teams were conscious of and responsive to shifts in how each bank understood its resource environment. In general, these patterns suggested that the banks were adapting simultaneously to the requirements of the more critical internal and external resource providers (Pfeffer \& Salancik, 1978). Evidence suggested that, whenever possible, resource providers were selected on the basis of fit with the strategic orientation at the time of their selection and the availability of talent aligned with that strategic orientation. For instance, in the interview described above, the CEO mentioned selecting board members initially on the basis of their alignment with the green mission. Some of the previous partners in a previous bank board were excluded (to their irritation) because they were "right-wing nuts" and the CEO wanted no "pushback" in his senior leadership team. When selection based on fit was not possible, congruence between the strategic orientation and the various resource providers was achieved by adapting the strategic orientation, which in turn led in some cases to the restructuring of some of the internal and external resource providers of the bank. Thus, when regulators, investors, and the market "pushed back," the bank adjusted its strategic orientation in favor of the banking logic.

The final step of the analysis was to confirm our preliminary findings in the larger set of interviews and in the archival evidence of the bank's strategic priorities. The theoretical lens developed through the evolution of the bank until its establishment was confirmed further when, by using that lens, we successfully made sense of the re-founding of GREENWEST based on a 
green reorientation. In support of this confirmatory analysis, we used ATLAS.ti searches for keywords including "adapt," "change," "strategy," "mission," "idea," "investor," and "profit" to ensure that we had not missed alternative explanations for the evolution of the strategic orientation.

\section{HYBRID ENTREPRENEURSHIP IN UNCERTAIN AND FLUCTUATING ENVIRONMENTS}

GREENWEST and GREENSOUTH, our two research sites, were founded two years apart and were among the first green banks to be established in the United States. Both banks sought to establish the new form of green banking, to be comprised of organizations engaged in banking activities that aimed to both advance the cause of sustainability and make a financial profit. The visions of the early members of the senior leadership teams of the two organizations were remarkably similar. One cofounder of GREENWEST called himself an "innovative banker" whose goal was to get "exceptional returns." Another cofounder stated that GREENWEST bank would be the first to focus on both "banking" and the promotion of "green and sustainable resources." Similarly, the founder/CEO of GREENSOUTH called himself "a rabid environmentalist" but also "a rabid capitalist." In both cases, founders and directors aspired to make a real impact on the environment and were excited about how their "business model" had the potential to "define the future of the U.S. banking industry."

These "green" privately owned banks should not be confused with "state green banks," other governmental state-level financial institutions that emerged later to provide low-cost financial services for clean or renewable energy projects. The first among those other institutions was Connecticut's Clean Energy Finance and Investment Authority (CEFIA), established in 2011 to leverage millions of federal funding in support of state-level clean energy initiatives. Unlike those government institutions, GREENWEST and GREENSOUTH were "regular" privately owned local community banks.

The founding process of GREENWEST and GREENSOUTH followed a startup process consisting of steps that are typical to the founding of a new bank. There are four sequential steps that correspond to the acquisition of critical tangible and intangible resources: (1) assembling a core founding group of directors with appropriate connections, legitimacy and skills; (2) obtaining regulatory approvals; (3) securing capital resources; and (4) facing 
the market for both employees and customers. This process is wellestablished and was closely followed by more than 100 new community banks per year in the years preceding our study (Almandoz, 2012). There is a "ready-to-wear" model (Battilana \& Dorado, 2010), a well-defined formation process, and eager support from bank regulators, consultants and lawyers (DiMaggio \& Powell, 1983) to assist founders in this endeavor.

\section{GREENWEST's Founding Process}

The timeline of GREENWEST's founding is summarized in Table 2 from assembling a core founding group of directors (2003-2004), to obtaining regulatory approvals (2005), securing capital resources (2004-2006), and facing the market for employees and customers (2006-2007). Each of these steps entailed an encounter with GREENWEST's resource environment, with resulting consequences for the composition of its senior leadership and strategic orientation.

\section{Local Context and Founding Group}

GREENWEST was established in a region of the United States that one executive referred to as "the Mecca of all things green." In an organizational document explaining its initial strategy, GREENWEST specified that the area was chosen because of "the critical mass of clean businesses and sustainability focused organizations in the region" (page 2). The 15-page executive summary of the document provides abundant detail on the bank's strategy to target green businesses, and people and organizations committed to sustainability. Ten different sectors are mentioned as potential clients of the bank - including organically and sustainably produced food, green buildings and green consumer products. Specific examples are mentioned of potential customers and their banking needs. The document lists 16 sample industry associations or cooperative organizations with whom the bank could partner and mentions that board members and organizers of the bank have existing relationships with 539 different organizations in the bank's home region alone: 178 in clean energy, 184 in organic foods, and 177 in green buildings.

GREENWEST's founding group was deeply embedded in green institutions, locally, nationally, and internationally, and included a broad base of directors with a strong commitment to, and affinity for, both financial and green logics, including renowned green activists and businesspeople. One of the bank founders had, years before, been instrumental in persuading large 


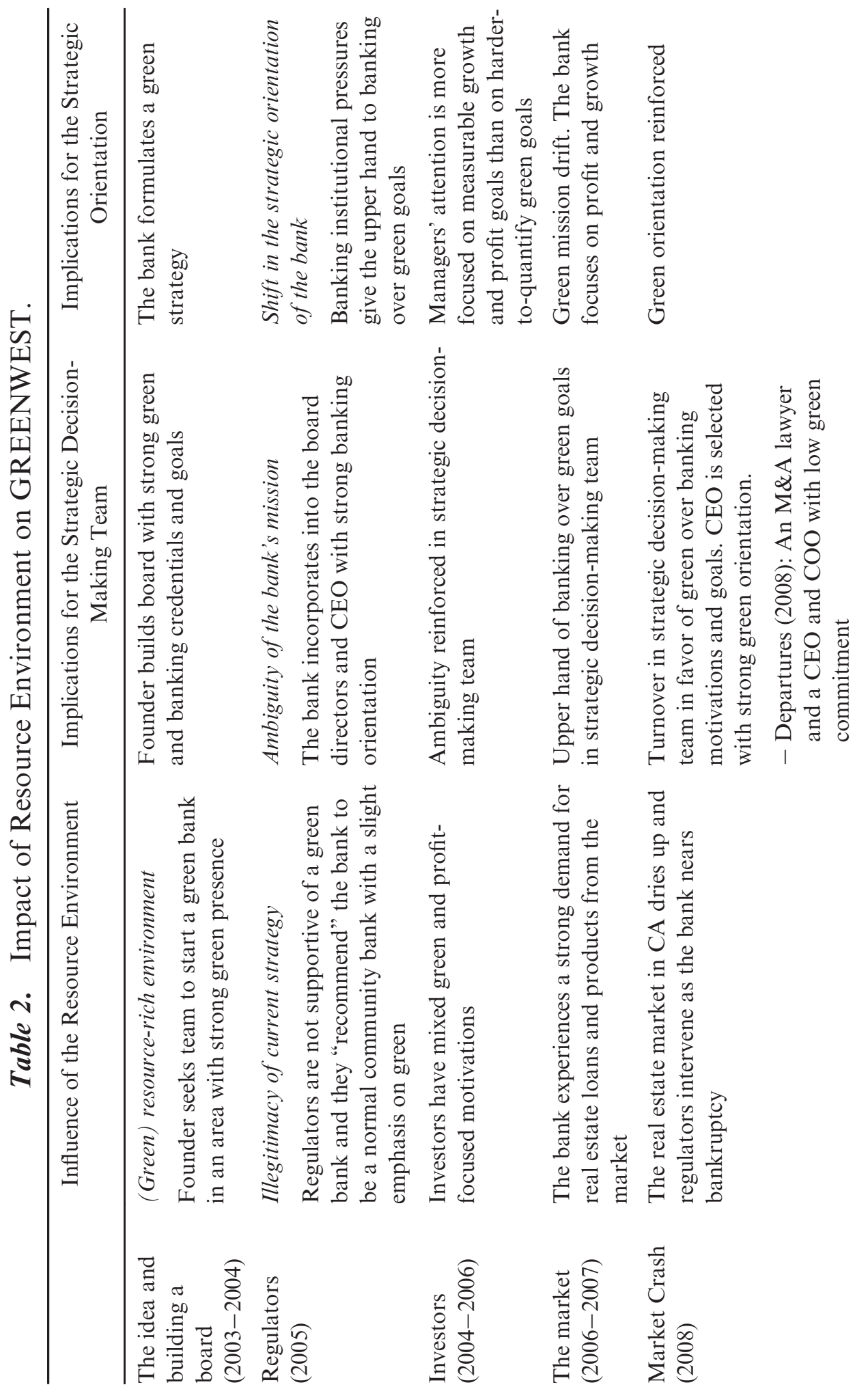




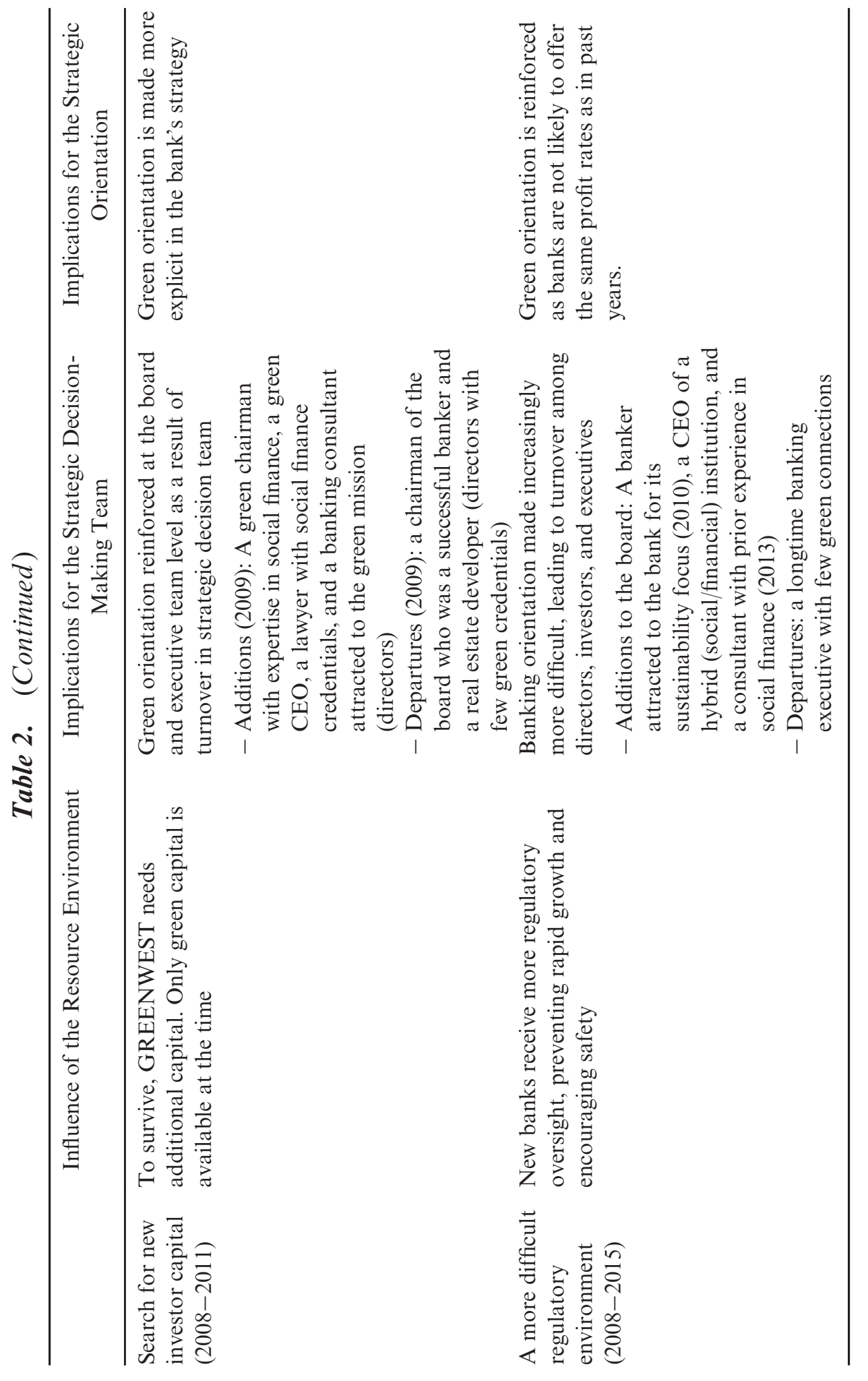


Table 3. Core Founding Group's Involvement in Sustainability at GREENWEST.

- Cofounder of a group of business leaders advocating environmental goals

- CEO of a social finance nonprofit focused on environmental sustainability

- President of an organic and sustainable food product consulting firm and former president of the Organic Trade Association

- President of a leading green building and energy efficiency company

- Partner of venture capital fund focused on clean technology investments

- President of a building and engineering firm focused on green and sustainable buildings

- Director of a major private foundation with a strong focus on environmental sustainability

- Director of an investment banking firm with a specialization in clean energy

institutional investors in the region to invest in green enterprises. Others in the core group of founders had created organizations and investment funds to promote green entrepreneurship. The cofounders then hired a CEO to run the bank. (see Table 3 describing the backgrounds of board directors and organizers of the bank).

\section{Interactions with Resource Environment}

In its initial stages of development, the essential resources acquired by GREENWEST were largely controlled by actors embedded in the green logic. However, despite the strong green orientation of the core founding group of directors, GREENWEST's strategic orientation became progressively more banking-oriented and less green. As one founding director explained, this shift to a banking orientation was heavily influenced by a decision to hire a CEO who was a seasoned banker, but did not have a strong commitment to sustainability. While the ideal candidate would have demonstrated operating experience within both the banking logic and the green logic, such a candidate proved impossible to find. The hire of a banking oriented CEO reinforced the banking logic, shifting the balance of representation of banking and green logics within senior leadership. (see Table 4 for detailed evidence about this period).

GREENWEST's move toward the banking logic continued once it commenced operations. GREENWEST's initial business plan, approved by regulators, projected a loan portfolio comprised of 50 percent real estate loans. Relative to loans made to clients in other sectors, these loans were typically not viewed as enacting the green logic, as GREENWEST borrowers rarely committed to build according to sustainable standards. However, growth in the local real estate market during the initial years of GREENWEST's existence shifted available 


\section{Table 4. Illustrations of the Impact of Resource Environment on GREENWEST.}

The idea and building a board (2003-2004)

Regulators (2005)

Investors

(2004-2006)

The market (2006-2007)
The market was ideal for a new bank that could potentially make a difference in the banking sector.

Founding member. We saw the need. There is a need to be a successful business in order to grow and generate resources to make a difference in the environment.

Employee. I saw the opportunity to be on the cusp of something new, different and enduring. We would like that in 10 years everyone will be wondering, "Why weren't we always banking like this?"

Press release. We are the bank for people leading the way to a more sustainable world. We are a mission driven bank focused on sustainability; that means we work to have positive environmental and social impact, as well as make a profit, and we support businesses that do the same.

Business Plan. The bank's market [in the area], which is underserved by commercial banks currently operating in the local market and is also home to a thriving and highly connected network of rapidly growing clean businesses and leading sustainability focused organizations.

Regulators pushed the bank to give more priority to banking goals and less to green goals

Founding member. I think the regulators focus on risks, and not necessarily on the other issues that need to be addressed in society. So an idea that is new is sometimes challenging. If you focus on green business you are going to be too concentrated from a risk standpoint. So, [regulators] actually had a lot of input initially into how we evolved the business model. They were definitely the hardest ones to please. They actually said, "We want you to act as a community bank and serve the rest of the community as well." That's what they required us to do.

Second CEO. While the idea of a green bank was highly important to the bank founders, the bank opened as a more general community bank that had a focus on green. There was a lack of clarity up front about what the green strategy was going to be.

Investors focused the bank on banking goals

Second CEO. There were two kinds of investors. The 'fast banking' investor was asking how fast can you grow? How high can your ROE be and how big an exit can we achieve by selling this bank in 10 years? And then there were 'slow banking' investors, who were in this for the long run and not looking for an exit strategy.

The market opened attractive opportunities for banking goals

Second CEO. I would say that in the end the idea was never really clearly laid out. What did success look like? In the end, there were 
definitely competing goals [in the board]. The bank was formed to be green, but we wanted to grow as fast as we could and that means we could do a lot of non-green stuff in the interest of growth.

Second chairman. When we were looking to hire a CEO it was hard. We couldn't find any seasoned banker who was really interested in the mission. I could tell immediately that they were "Yeah, yeah, yeah, we are happy to do this green stuff," but it was more like icing on the cake. You could just feel that they were not going to build a different kind of culture in the organization.

Second chairman. We grew really, really quick and probably we made some mistakes in the early days by feeling that we needed to get to profitability very quickly, and therefore put a lot of loans on the books. So the bank got ahead of itself ....[At the end of the run, some founders] "were shocked that an important part of lending we were doing was not mission related."

Employee. Dollar signs and growth were more important than truly adhering to the [green] mission.

Market Crash (2008) The market crash shrinks the resource environment and returns the bank to the original green mission for which there are still available pools of resources

Second CEO. It is not about building for exit multiples. Growth and profitability are essential and important, but they are means-goals and not end-goals. The end-goal has to be building a sustainable community.

Search for new investor capital (2008-2011)

The reinforced green strategy of the bank limiting profit expectations changes the investor composition

Second CEO. Some investors actually love what we are doing and a lot of them are doubling down. One 10-percent investor is going to become a 25-percent investor and a 1-percent is going to become a 10 -percent investor. So we have some significant increases from existing investors as a result of this greater mission clarity. But there are others who are unhappy so I am connecting them with our market-maker and they want out. So there will be some shifting among those investors.

A more difficult regulatory environment (2008-2015) Increasing regulatory oversight limiting growth Second CEO. Our IRR will get up to 10 percent and that's probably the new normal for community banking 
opportunities toward real estate. Although unanticipated, the board and management viewed the boom in real estate lending opportunities as the most promising opportunity to grow quickly and most profitably. As a result, GREENWEST's proportion of real estate loans as a part of the overall portfolio was 65,82 , and 88 percent at the end of the first, second, and third years, respectively. So while the bank had opportunities to make loans to green customers, the growing attractiveness of the local real estate resulted in practices more consistent with the banking logic, especially the goal of rapid bank growth, and less consistent with the green logic. Thus the bank slowly drifted away from the green strategic orientation.

GREENWEST's rapid growth was interrupted suddenly by the market crash in 2008, which caused the market for real estate loans to plummet. The result was a much less attractive real estate market and a dramatic turnover in the board of directors and executive team. As a member of the founding team and board mentioned, "The chairman of the board resigned and we really needed to make some changes with the management. So we basically reconstituted the board and hired a new CEO." As it attempted to shift its strategy away from its failed real estate loans, the bank required new financing. During this period, it discovered that investment capital was only available within the green investing community, whose normative motivations for providing financing had persisted despite the crisis. The bank's strategic orientation thus shifted back toward the green logic. This shift to the green logic and away from the banking logic was reinforced again when the regulatory environment after the crisis (2008-2011) resulted in more stringent regulatory constraints on banks' growth and profitability targets. This shift in the strategic orientation of the bank was also accompanied by significant turnover in the senior leadership of the bank that resulted in a greater proportion of members representing the green logic.

In summary, GREENWEST was founded with a strong green orientation that progressively weakened through the course of the founding process as it was forced to seek resources from the banking sector and as it was tempted by opportunities for growth. But shifts in the resource environment as a result of the crisis led to a refocusing of the bank's strategic orientation on green products and customers, which also corresponded to a re-shuffling of the bank's investors and organizational members toward those motivated by the bank's green orientation. Table 4 shows qualitative evidence from interviews and archival data that supports the story of how uncertain and fluctuating resource environments determined the 
composition of the decision-making team and the orientation of the bank's strategy.

\title{
GREENSOUTH's Founding Process
}

\begin{abstract}
The timeline of GREENSOUTH's founding is summarized in Table 5 from assembling a core founding group of directors (2006-2008), to obtaining regulatory approvals (2008), securing capital resources (2007-2008) and facing the market for employees and customers (2007-2009).
\end{abstract}

\section{Local Context and Founding Group}

GREENSOUTH began the process of opening a green bank one year after the founding of GREENWEST. In stark contrast to the Western state, the Southern state was viewed by some GREENSOUTH executives as "the land of the Neanderthal when it comes to sustainability," In a standard document describing the bank's strategy, GREENSOUTH provides far fewer details than GREENWEST regarding local connections with green organizations beyond the commitment and personal involvement of three board directors. One of them is an "internationally known spokesperson" for the environment; another is actively involved in 16 green associations, some local, some national, and some international; and the third, the main founder and CEO, has served as chairman for a political action committee advancing a green cause. Reflecting a perception that the bank's focus on the sustainability would not be appreciated by regulators, GREENSOUTH does not emphasize its green mission in that official document.

Prior to founding GREENSOUTH, its CEO and founder had extensive experience as a banker. Confident because of his prior success in founding another bank, and inspired by the story of the founder of Patagonia, a prominent sustainable apparel company, he decided to start a values-driven bank that would combine his passions for banking and the environment. Based on these influences, he saw an opportunity to pair his professional skills and personal passions by launching a green bank in a region where he was born and had always lived. He hand-picked a core founding group from among friends and family and from business partners, some of whom had been directors of his prior bank's board of directors. (See Table 6 describing the backgrounds on sustainability of board directors). 


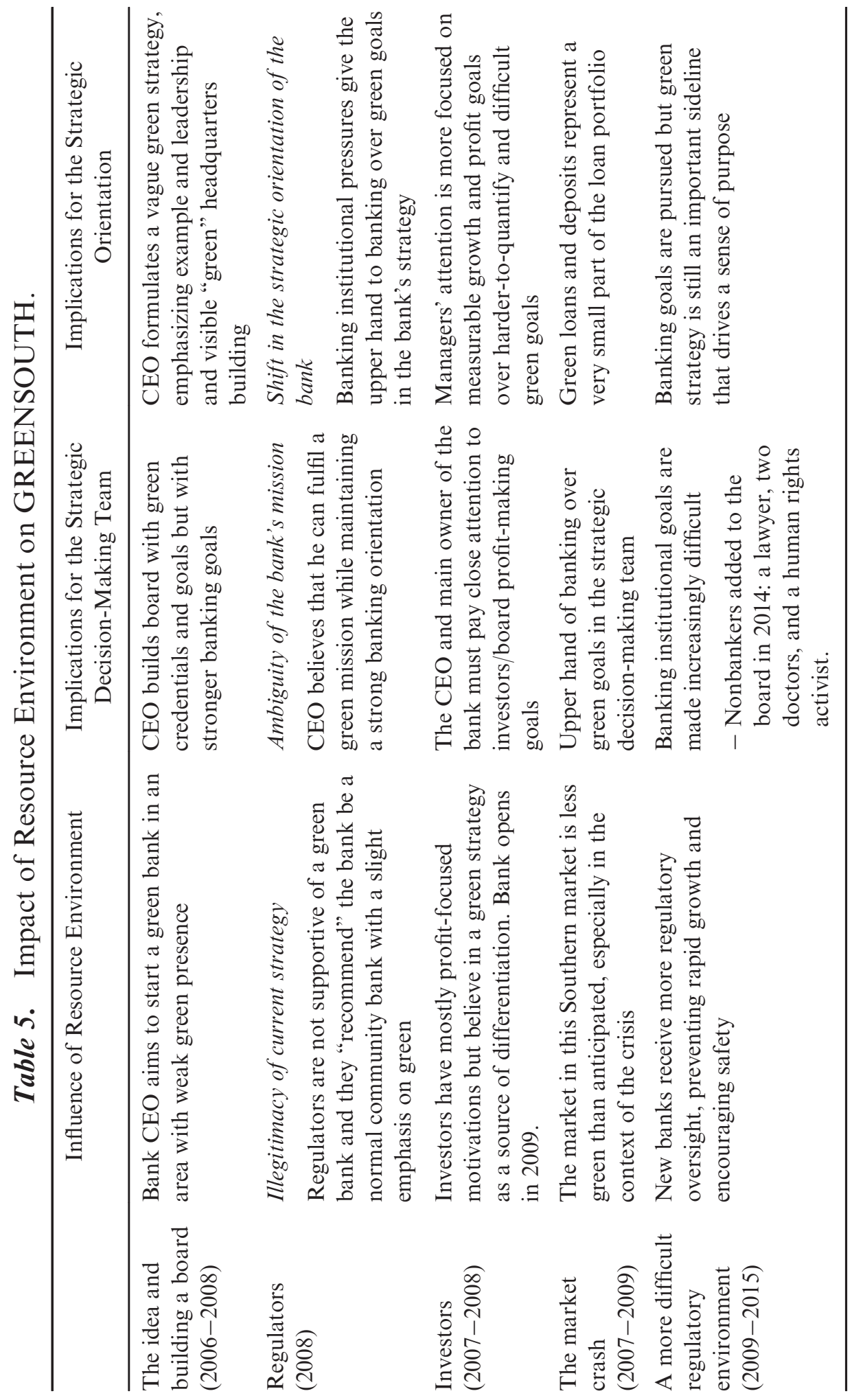


Table 6. Core Founding Group's Involvement in Sustainability at GREENSOUTH.

- The CEO is Chairman of a political action committee to purchase and preserve public land.

- A respected pastor, leader in a large evangelical community who has been named one of the top 15 religious environmental leaders worldwide.

- A biologist and entrepreneur who started a local tissue laboratory and nursery specializing in the production of indoor tropicals and fruits and who is involved in national and international plant, foliage, nursery, and horticulture societies.

\section{Interactions with Resource Environment}

Subsequent encounters with the resource environment had implications for the composition of the strategic decision-making team and the strategic orientation of the bank, which made the bank progressively more focused on its banking orientation. During the regulatory approval process, state banking regulators strongly suggested that the green logic should not be the main focus of the bank. Although the Founder/CEO sought investors oriented toward green issues, he was unable to find many such investors, and the bank took capital from investors who viewed the bank primarily as an opportunity to pursue financial returns. The unavailability of green investors became even more pronounced as the financial crisis deepened. Initially the founding group was aiming to require a minimum $\$ 100,000$ investment per person but financial volatility led them to drop this minimum required investment to $\$ 60,000$. An initial premise of GREENSOUTH's strategy had been to use banking relationships as a way to encourage clients to make sustainability-oriented investments (i.e., in energy-efficient buildings); however, the crisis also limited the feasibility of such investments for GREENSOUTH's clients.

Following the crisis, GREENSOUTH continued to pursue green opportunities, but primarily inside the organization. Opportunities to make loans to green companies and industries remained sparse, so the Founder/CEO focused on alternative means to advance the cause of sustainability. For instance, GREENSOUTH designed their internal operations to focus on sustainable principles such as operating without physical paper. GREENSOUTH also sought to use the bank as a platform for sustainability by drawing media attention to its sustainability mission.

Table 7 shows qualitative support for the evolution of GREENSOUTH's strategic orientation as a result of an increasingly difficult resource environment forcing the bank to focus more on its banking orientation. Unlike the example of GREENWEST's process of formation, there were no 


\section{Table 7. Illustrations of the Impact of Resource Environment on GREENSOUTH.}

The idea and building a A committed environmentalist and successful banker wants to make board (2006)

a difference in a territory that is not keen on sustainability

Founder. I am a committed environmentalist, and I love banking. A rabid environmentalist and a rabid capitalist. So I was running with a friend, and we talked about it, and he said, "It's your destiny. You need to merge the two things." That's the genesis of it.

Founder. There were a handful of key people [on my previous bank board] that I wanted to have on the board who would be understanding and supportive of sustainability and there were plenty of others who would have liked to join me, and in fact some of them, once they found out, came to me and were irritated when I did not invite them, but I didn't want anybody pushing back

Executive. "This is the land of Neanderthals when it comes to sustainability."

Executive. We are very excited about this business model, and we believe it will define the future of the U.S. banking industry. To my knowledge, this will be the first bank of its kind to promote positive environmental and social responsibility while providing for increased profits for investors and clients.

Regulators (2007) Regulators and consultants pushed the bank to give more priority to banking goals and less to green goals

Founder. Regulators wanted to put us into the niche bank category [a bank serving a specialized and undiversified sector] and all our consultants and advisors said, "You don't want to do that." So, we said, "No, we are a community bank. We are not a niche bank." I am not sure that was the right decision in the end, because we ended up having to straddle between what is seen as traditional community banking and what we were really doing in terms of our mission.

Founder. At that point, I said, "Whoa, whoa, whoa! We're a bank, we're a bank, we're a bank! If somebody comes in and they want to do a 5-acre slash-and-burn real estate development deal, we're still going to do it because we have shareholder value to maintain. We're going to try everything we can to teach them a better way, but we're still going to do it. We won't want to do it and we will kick and scream the whole time." So finally I got them to back off.

Investors (2007-2008) bank

Founder. [Reported that an investor who agreed to invest $\$ 500,000$ in the bank said]: "I don't believe in this [green] stuff, but yours is the best marketing ploy I have ever seen." 
The market crash (2008-2009)

A more difficult regulatory environment (2008-2015)
The market in this Southern market is less "green" than anticipated because of the crisis

Founder. Initially, the emphasis on sustainability went very well. But as things began to change all that became almost a non-issue. Nobody wanted to hear it; no one wanted to talk about it, which was really disturbing to me, because that was the genesis of the whole idea.

Founder. We opened at the peak of the great recession and nobody, absolutely nobody, has any interest in doing anything sustainable. People are having trouble and when they do they just want to be able to meet their mortgage payment, they don't care about green.

New banks receive more regulatory oversight, preventing rapid growth and encouraging safety and causing a renovated emphasis on the green mission

Employee. I think it's better for the bank to be here [rather than in the local environment of GREENWEST] because it has a chance to be the leader whereas GREENWEST may just be one of [many organizations] in [that area] doing this. Here GREENSOUTH has a chance to be on the leading edge to help promote what it feels strong about. It stands out more here. [So] in order to grow a movement this is a better place to do it.

fluctuations in the relative abundance of resources aligned with the green and banking logics; there was only of a steady decline in both banking and green available resources.

\section{Long-Term Strategic Orientation}

These two organizations, despite the similar intentions of their founders, ended up with significant differences in the degree to which goals connected with the green and banking institutional logics were realized in their strategies.

GREENWEST

GREENWEST emerged from the financial crisis operating with a strong green logic, despite its shift toward the banking logic prior to the crisis. The green strategy at GREENWEST focused on three aspects of its strategy. First, the bank committed to focusing client acquisition on companies already committed to sustainability, either because their business was in a 
green or sustainable sector, or because they made a clear commitment to operate in a sustainable fashion. As a consequence of its client selection, GREENWEST pursued modest growth and limited its own potential for profitability. Clients would be asked to take a survey every year and, based on the survey, they would be classified as either "learners," "achievers," "leaders," or "champions." The bank also developed toolkits with green recommendations and resources.

Second, bankers were trained to become trusted advisors on sustainable practices. The strategy involved helping clients become more environmentally sustainable and developing to that end a green expertise so that GREENWEST's bankers could become trusted advisors, especially adept at helping customers "unlock the economic value of sustainability" through branding and marketing practices, hiring and retaining employees, cost savings, and access to meaningful networks of similarly committed organizations and individuals.

Third, the renewed alignment with the green strategy entailed presenting a quarterly sustainability report to the board of directors, including aggregate scores on sustainability. The board also planned to review the bank's progress each year in fulfilling its green mission. To commit even more explicitly as a matter of governance to the green strategic orientation, the bank chose to become a B Corporation, joining other hybrid companies with both profit and nonprofit goals. Even though becoming a B Corporation currently had no legal consequence in the GREENWEST's home state, it was a way to signal the organization's commitment to a triple bottom line (return to shareholders, to employees, and to the environment). Bank investors were thus forewarned that maximizing value to shareholders was not the bank's sole purpose or even its central purpose.

\section{GREENSOUTH}

GREENSOUTH did not commit itself to serving only customers committed to green causes, finding insufficient demand for green banking services, nor to make its bankers experts in sustainability. It also did not establish governance practices to measure the degree to which the bank was serving a green mission. GREENSOUTH's strategic orientation was instead focused on internal operations rather than in its relationships with external stakeholders. First, they built a landmark headquarters building that received platinum LEED certification - the highest level. Living out their mission in the "land of the Neanderthals," where green concerns were not legitimate involved, attracting considerable media attention. GREENSOUTH's building served that purpose: it was built partly from recycled materials and had electric 
vehicle charging stations, larger windows to receive natural lighting, solar roof panels, and multiple other green and sustainable features.

Second, the bank operated sustainably, in a largely paperless fashion, and offered incentives to employees and customers who made investments in products and services aligned with green causes, such as purchasing energy-efficient cars, and remodeling homes to improve energy efficiency. Because of the crisis and the lack of local interest in sustainability, less than 10 percent out of $\$ 138$ million in the loan portfolio four years after establishment was composed of green loans, including loans to construction, landscaping, farming, nursery, organic foods, solar energy, medical, and water distribution companies. Green deposits comprised less than two percent out of $\$ 171$ million as of that time.

In sum, compared to that of GREENWEST, GREENSOUTH emphasized the green logic primarily through internal practices and its public example, rather than through monitoring the green practices of its clients. The green mission was promoted in the bank through personal influence, mostly that of the CEO. Some bankers told stories about the bank's impact, one person at a time, leading to more hybrid cars purchased, and incandescent light bulbs being replaced by florescent or low-voltage bulbs. As one banker put it, "You can tell that you are having an impact and making a difference when a client tells you, without you asking, about a new sustainable practice he or she is following."

\section{DISCUSSION}

Our findings suggest that innovative hybrid ventures face complex and uncertain resource environments and that this uncertainty plays an important and nuanced role in shaping the strategy of the organization. In particular, we find that the two banks' strategies emerged through an interactive process of searching for alignment among the uncertain local resource environment, the composition of the senior leadership team, and the strategic orientation of the bank.

For the two green banks we studied, the search for alignment between these elements began early in the founding process, before the banks were operational. During the process of regulatory approval and initial investment, both banks experienced interactions with regulators and investors who were more embedded in the banking logic. These initial encounters with the local environment also shifted the strategic orientations of both 
banks away from the green logic and toward the banking logic. In the case of GREENWEST, this shift was due to unexpectedly high demand for real estate products. GREENSOUTH shifted toward the banking logic upon finding that the local appetite for financial services among sustainabilityoriented clients was unexpectedly low, a pattern exacerbated by the financial crisis. The financial crisis had a different effect in the Western state, however, where the resource environment associated with a banking logic declined as the green bank category become much less appealing to traditional investors. This increased comparatively the availability of green clients and investors, pushing GREENWEST to shift back toward the green logic in its strategic orientation. Green investors, bankers and board directors rescued the bank by providing or finding access to new resources in exchange for a more explicit commitment to a green strategic orientation and to changes in the bank's board and management teams.

Our analysis revealed the outsized influence of uncertain or unknown resource environments on the institutional composition of the banks' senior leadership. Additions to senior leadership teams have significant influence on the banks' strategic orientation, as individuals function as "carriers" of the logics to which they have previously been exposed (Scott, 1995). Decisions about executive hiring and board member transitions were made according to the current strategic orientation of the bank and to the availability of talent that represented these logics and satisfied other requirements for these positions. In some cases, the limited availability of talent led a bank to select a leader who was not aligned with its current strategic orientation, such as when GREENWEST hired a CEO who primarily followed the banking logic. Despite the commitment of the founding team to the green logic, it could not find an experienced banker who also possessed experience in, and commitment to, the green logic. Due to the general continuity of senior leadership, this moment of transition had a persistent effect on the banks' strategic orientation until the leadership changed some years later.

The changing state of the local environments in the West and the South is necessary but insufficient to explain their influence on the trajectories of each bank's strategic orientation over time. This is because the changing environments were viewed through the lens of the logics represented by each bank's senior leadership. For instance, the drift of GREENWEST toward the banking logic when the real estate market became especially attractive required not only environment change, but the presence of a strong banking perspective within the senior leadership team. Members of the latest senior leadership team of GREENWEST at the end of the time 
period examined criticized the bank's "mission drift" during its early life and the failure of the senior leadership team at that time to maintain the bank's green strategic orientation. At every step of the way, choices were made reflecting the interests and motivations of decision-makers within the banks. Some of those choices involved incorporating other members into the decision-making teams, members with their own agendas perhaps aligning differently with green and banking institutional logics. It is likely that factors such as the availability of senior leadership aligned with the current strategic orientation would have led each bank to a much different strategic orientation.

Fig. 1 summarizes the relationship between those factors. The environment provides multiple resources, including people (directors for the board, bank experts, and customers), money (investment capital and deposits), local networks, regulatory approvals, etc. The timing when those specific resources are needed and their availability at that time is likely to shape the strategic orientation of the bank directly at first (as the bank responds to environmental demands) and then indirectly (as the senior leadership team is also shaped by prior institutional pressures from the environment). The process is gradual and path-dependent since what happens at the early stages of the process has an impact in successive steps (David, 1994; Sydow, Georg, and Koch, 2009). Senior leadership teams (starting with the founder and progressively incorporating other decision-makers) interacted

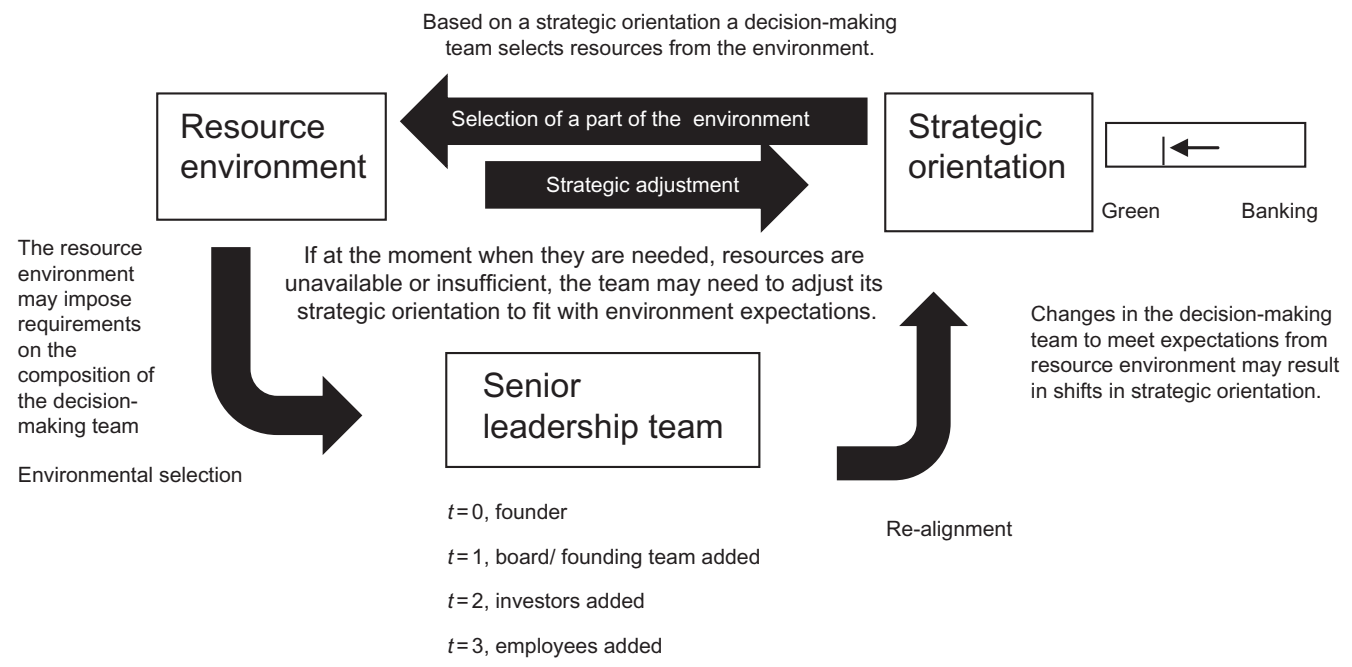

Fig. 1. Dynamic Relationship between Resource Environment and Strategic Orientation. 
with resource environments and one step at a time defined the banks' strategic orientations.

This article makes three important contributions. First, it contributes to the literature on organizational emergence in the context of organizations dependent on multiple and uncertain resource environments. This article shows a gradual, dynamic and path-dependent interplay between agency and resource environments that ultimately results in the strategic orientation emerging from the founding period, which cannot be regarded as truly finished until the organization opens and has operated for a few years (DiMaggio, 1988). Founders may have an organizational idea with an implicit orientation emphasizing one logic over the other, and based on such orientation, they may select and invite into the core founding group, and later into the investor and employee group, resource providers who are aligned with this strategic orientation. But if those leaders are not perfectly aligned in their motivations, their selection may result in shifts or at least ambiguity in the organization's strategic orientation. When founders are strongly dependent on multiple resource environments to build up an organization, they may need to relinquish some degree of control over the organization's strategic orientation. If those resources are multiple and uncertain, the direction of the strategic orientation may be less predictable, with uncertain consequences for the stability and commitment of existing organizational members.

Perhaps because research on environments has generally focused on well-defined, predictable environments, the impact of environments on the emergence of new organizations has been treated with an air of inevitability. The more complex setting in this article illustrates that the choices of founders, and the timing of those choices, could affect the internal composition of senior leadership teams, the representation of institutional demands, access to resource environments, and the trajectory of the organization's strategic orientation. Our research setting allowed us to view the founding process as a series of engagements with the external environment, leading to a cycle of perceived environmental change, adjustment of the strategic orientation of the organization, and senior leader selection. While our study focuses on the setting of green banking, the implications of this model would be the same for other contexts where the influences from those uncertain and multiple resource environments may be simultaneous rather than sequential.

Second, this article contributes to research on internal representation of institutional logics within hybrid organizations (Pache \& Santos, 2010). Much research on entrepreneurship and institutional theory views new 
ventures creating new organizational forms, however illegitimate to the external environment, as strategic actors with well-defined preferences, operating in well-defined environments (Aldrich \& Fiol, 1994; Lounsbury \& Glynn, 2001). Our findings challenge this assumption and are suggestive of mechanisms by which the complexity of external environments manifests within strategic decision-making teams. In other words, the composition of strategic decision-making teams is not only an independent variable influencing how the organization interprets environmental stimuli and responds to institutional pressures, but it is itself an outcome of those stimuli and pressures. Strategic responses to environmental stimuli and internal representation of competing logics (banking and green) within the organization's strategic decision-making team are likely to be in a state of constant dialogue and mutual influence as the boundaries of the organization expand to include more strategic decision-makers beyond the founder. This recursive influence has implications for the literature on hybrid organizations and their strategic responses to competing institutional demands, which has tended to view strategies as outcomes of internal representation without exploring the recursive nature of such relationship (Almandoz, 2012; Pache \& Santos, 2010).

Third, this article contributes also to research on founder imprinting (Marquis \& Huang, 2010; Marquis \& Tilcsik, 2013). Founder commitment to green and banking logics was similar in these two organizations. Thus no large differences in the strategic orientation of these organizations would be expected based solely on characteristics of founders. This article shows that the strategic orientation of an organization depends not only on founder characteristics, but may be seen as an outcome variable of an endogenous series of senior leader imprints. Founders bring to the organization an implicit strategic orientation and, based on this initial orientation, select other senior leaders from the pool of accessible candidates in their resource environment. Such recruited members may independently influence the organization's strategic orientation with their own distinctive motivations and preferences and the influence may in fact be mutual and recursive until, at the end of the imprinting process, the organization emerges with a more defined strategic orientation. This orientation may be crystallized through aligned expectations, concrete practices and experiences, and governance mechanisms. Future research may consider the possibility that in the long run, the organization's mature strategic orientation governs the internal representation of external logics imported via the selection of senior leaders. 
This article illustrates the simultaneous influence of three factors on strategic orientation: internal members of strategic decision-making teams acting as carriers of competing institutional logics; multiple resource environments that become more relevant at key moments of the founding process and that may become more available in certain geographic settings; and exogenous variation in economic and environmental conditions. This last factor may alter the expectations of organizational members to reach their specific goals and may affect also the size and accessibility of certain resource environments. This exogenous variation is likely to alter the negotiation power of members within decision-making teams aligned with distinct institutional logics. This article shows how the impact of temporal shocks (Schoar \& Zuo, 2011) is transmitted through internal and external mechanisms to influence which features of the environment get imprinted upon the organization's strategic orientation.

Important boundary conditions of this study include the very central role of regulators in the banking sector, who have a strong hand in shaping the strategic direction of organizations, and the presence of a powerful, unexpected environmental change - the financial crisis of 2008. It is evident that these strong environmental forces had an important impact on the strategic orientations of the two ventures we studied, but it is not clear whether similar effects would be observed in the absence of these conditions. The high degree of environmental uncertainty in this study makes more visible the mechanisms by which such uncertainty has an important and nuanced role in influencing the strategy of certain organizations. Such influence would be less relevant if the institutional context were less uncertain or intrusive, or if the initial idea from the entrepreneurs were less new and more legitimate according to the logics traditionally governing that sector, or if the founders had access to more resources without having to depend as much on the environment's approbation. Under those conditions, the initial idea would be likely to have more persistent influence on the ultimate strategy of the new organization. The power of the environment in this empirical setting is important, however, to shed light on the mechanisms by which organizational strategy, organizational environment, and leadership teams mutually influence one another.

Another limitation of the present study is that we do not directly observe how organizations anticipate and respond to environmental uncertainty a priori - before perceptions of the resource environment shifted. The influence of environmental uncertainty was observed indirectly through the unexpected resistance from regulators to the green banking model, the tempting opportunity arising from the growth of the real estate market in 
the West, and the financial crisis which altered the availability of resources. More research is needed to explore how decision-makers approach environmental uncertainty a priori, before reactions from the environment force organizations to make adjustments. Future research could build on these ideas through ethnographic and in-depth interview exploration of innovative hybrid organizations during their founding process.

An study focuses on the impact of institutional forces on the strategies of organizations. Other non-institutional forces may also cause environmental uncertainty - new competitors, market or strategic innovation, etc. - and could similarly give rise to an ongoing interaction between internal leadership teams, resource-constrained environments, and dynamic organizational strategies. More research is needed to explore, in real time, the mechanisms by which new organizations in those uncertain environments cope with different sources of uncertainty - both institutional and non-institutional. For example, future research might examine how the composition and diversity of top leadership teams is affected by environmental uncertainty and how and under what conditions the organizational purpose and resulting operational strategies of an organization become more focused or more open or ambiguous.

One interesting aspect of the empirical setting is that the products of green banks are very standardized and general (loans and deposits). This raises the question of whether the strategic orientation of the bank could be more flexible as a result of offering stable products that are universally recognized. As a result of that flexibility the likelihood of new organizational forms emerging may be higher than in other settings where the products and services offered are not as common or standardized and where environmental resources may be less forthcoming.

While this article has focused on the emergence of new and novel organizations, some of these same mechanisms driving an interaction between strategies, decision-makers, and environments could also occur within existing organizations. Leaders of those organizations could enable or constrain the alternatives available to organizational actors in a way similar to regulators in the market. The role played by external legitimacy and market demand in this study could be assumed inside existing organizations also by how proximate or distant is the proposed divisional strategy from existing practice and what is the likelihood that it will be opposed by political forces and other sources of organizational inertia. Organizations introducing new departments with different business models or strategies - for instance, a digital strategy - may require top leadership teams to bridge and negotiate new and old business approaches. The initial vision for the 
new digital department and for how it is integrated into a larger company may need to be adjusted as the division engages with distinct organizational decision-makers and as the composition of the division's decision-making team changes.

More research is needed to understand better under what conditions organizations introducing novel strategies fraught with uncertainty have frequent a priori exchanges with the resource environment and under what conditions the strategy is presented as a fait accompli. Steve Jobs, for example, was not known for consulting with the market about his new ideas and products. As he put it, "A lot of times, people don't know what they want until you show it to them." Some factors likely to predict a less frequent exchange with the environment may include the confidence or reputation of an entrepreneur, leadership team, or organization, and the material resources they own; the attractiveness or potential of the novel strategy and the threat of imitation by other competing organizations; and the complexity of the novel strategy. As a result, the relationship between new forms and their environments may not be fully knowable until it is realized in action.

\section{NOTE}

1. As quoted in BusinessWeek (May 25, 1998).

\section{ACKNOWLEDGMENTS}

Special thanks to András Tilcsik, Royston Greenwood, and Marya Besharov for their insightful comments on an earlier draft of this article.

\section{REFERENCES}

Adner, R. (2002). When are technologies disruptive? A demand-based view of the emergence of competition. Strategic Management Journal, 23(8), 667-688.

Aldrich, H. E., \& Fiol, C. M. (1994). Fools rush in? The institutional context of industry creation. Academy of Management Review, 19(4), 645-670.

Almandoz, J. (2012). Arriving at the starting line: The impact of community and financial logics on new banking ventures. Academy of Management Journal, 55(6), 1381-1406. 
Almandoz, J. (2014). Founding teams as carriers of competing logics: When institutional forces predict banks' risk exposure. Administrative Science Quarterly, 59(3), 442-473.

Ansoff, H. I. (1965). Corporate strategy. New York, NY: McGraw-Hill.

Ashforth, B. E., \& Reingen, P. H. (2014). Functions of dysfunction managing the dynamics of an organizational duality in a natural food cooperative. Administrative Science Quarterly, 59, 474-516.

Battilana, J., \& Dorado, S. (2010). Building sustainable hybrid organizations: The case of commercial microfinance organizations. Academy of Management Journal, 53(6), $1419-1440$.

Battilana, J., \& Lee, M. (2014). Advancing research on hybrid organizing - Insights from the study of social enterprises. Academy of Management Annals, 8, 397-441.

Besharov, M. L., \& Smith, W. K. (2014). Multiple institutional logics in organizations: Explaining their varied nature and implications. Academy of Management Review, 39(3), 364-381.

Boyd, B. (1990). Corporate linkages and organizational environment: A test of the resource dependence model. Strategic Management Journal, 11(6), 419-430.

Conrath, D. W. (1967). Organizational decision making behavior under varying conditions of uncertainty. Management Science, 13(8), B-487.

Cyert, R. M., \& March, J. G. (1963). A behavioral theory of the firm. Englewood Cliffs, NJ: Prentice-Hall.

David, P. A. (1994). Why are institutions the "carriers of history"? Path dependence and the evolution of conventions, organizations and institutions. Structural Change and Economic Dynamics, 5, 205-220.

Delmas, M. A., \& Toffel, M. W. (2008). Organizational responses to environmental demands: Opening the black box. Strategic Management Journal, 29(10), 1027-1055.

DiMaggio, P. J. (1988). Interest and agency in institutional theory. In L. G. Zucker (Ed.), Institutional patterns and organizations: Culture and environment (pp. 3-21). Cambridge, MA: Ballinger.

DiMaggio, P. J. (1991). Constructing an organizational field as a professional project: US art museums, 1920-1940. In W. W. Powell \& P. J. DiMaggio (Eds.), The new institutionalism in organizational analysis (pp. 267-292). Chicago, IL: University of Chicago Press.

DiMaggio, P. J., \& Powell, W. W. (1983). The iron cage revisited: Institutional isomorphism and collective rationality in organizational fields. American Sociological Review, 48(2), $147-160$.

Duncan, R. B. (1972). Characteristics of organizational environments and perceived environmental uncertainty. Administrative Science Quarterly, 17, 313-327.

Eisenhardt, K. M. (1989). Building theories from case study research. Academy of Management Review, 14(4), 532-550.

Emshoff, J. R., \& Freeman, R. E. (1981). Stakeholder management: A case study of the US Brewers association and the container issue. Applications of Management Science, 1, 57-90.

Finkelstein, S., Hambrick, D. C., \& Cannella, A. A. (2009). Strategic leadership: Theory and research on executives, top management teams, and boards. Oxford: Oxford University Press.

Friedland, R., \& Alford, R. R. (1991). Bringing society back in: Symbols, practices and institutional contradictions. In W. W. Powell \& P. J. DiMaggio (Eds.), The new institutionalism in organizational analysis (pp. 232-262). Chicago, IL: The University of Chicago Press. 
Greenwood, R., \& Hinings, C. R. (1996). Understanding radical organizational change: Bringing together the old and the new Institutionalism. Academy of Management Review, 21(4), 1022-1054.

Greenwood, R., Raynard, M., Kodeih, F., Micelotta, E. R., \& Lounsbury, M. (2011). Institutional complexity and organizational responses. Academy of Management Annals, 5, 317-371.

Greve, H. R. (2008). A behavioral theory of firm growth: Sequential attention to size and performance goals. Academy of Management Journal, 51(3), 476-494.

Haveman, H. A., \& Rao, H. (2006). Hybrid forms and the evolution of thrifts. American Behavioral Scientist, 49(7), 974-986.

Jay, J. (2013). Navigating paradox as a mechanism of change and innovation in hybrid organizations. Academy of Management Journal, 56(1), 137-159.

Johnson, V. (2007). What is organizational imprinting? Cultural entrepreneurship in the founding of the Paris Opera. American Journal of Sociology, 113(1), 97-127.

Knight, F. H. (1921). Risk, uncertainty and profit. Washington, DC: Beard Books.

Kraatz, M., \& Block, E. (2008). Organizational implications of institutional pluralism. In R. Greenwood, C. Oliver, R. Suddaby, \& K. Sahlin-Andersson (Eds.), Handbook of organizational institutionalism (pp. 243-275). London: Sage.

Lawrence, P. R., \& Lorsch, J. W. (1967). Differentiation and integration in complex organizations. Administrative Science Quarterly, 12, 1-47.

Loewenstein, J., Ocasio, W., \& Jones, C. (2012). Vocabularies and vocabulary structure: A new approach linking categories, practices, and institutions. The Academy of Management Annals, 6(1), 41-86.

Lounsbury, M., \& Glynn, M. A. (2001). Cultural entrepreneurship: Stories, legitimacy, and the acquisition of resources. Strategic Management Journal, 22, 545-564.

Marquis, C., \& Battilana, J. (2009). Acting globally but thinking locally? The enduring influence of local communities on organizations. Research in Organizational Behavior, 29, $283-302$.

Marquis, C., \& Huang, Z. (2010). Acquisitions as exaptation: The legacy of founding institutions in the U.S. commercial banking industry. Academy of Management Journal, 53(6), $1441-1473$.

Marquis, C., \& Lounsbury, M. (2007). Vive la resistance: Consolidation and community-level professional counter-mobilization in US banking. Academy of Management Journal, 50(4), 799-820.

Marquis, C., \& Tilcsik, A. (2013). Imprinting: Toward a multilevel theory. The Academy of Management Annals, 7(1), 195-245.

Mason, R. O., \& Mitroff, I. I. (1981). Challenging strategic planning assumptions: Theory, cases, and techniques. New York, NY: Wiley.

McMullen, J. S., \& Shepherd, D. A. (2006). Entrepreneurial action and the role of uncertainty in the theory of the entrepreneur. Academy of Management Review, 31(1), 132-152.

Meyer, J. W., \& Rowan, B. (1977). Institutionalized organizations: Formal structure as myth and ceremony. The American Journal of Sociology, 83(2), 340-363.

Milliken, F. J. (1987). Three types of perceived uncertainty about the environment: State, effect, and response uncertainty. Academy of Management Review, 12(1), 133-143.

Navis, C., \& Glynn, M. A. (2010). How new market categories emerge: Temporal dynamics of legitimacy, identity, and entrepreneurship in satellite radio, 1990-2005. Administrative Science Quarterly, 55(3), 439-471. 
Pache, A. C., \& Santos, F. (2010). When worlds collide: The internal dynamics of organizational responses to conflicting institutional demands. Academy of Management Review, $35(3), 455-476$.

Pache, A. C., \& Santos, F. (2013). Inside the hybrid organization: Selective coupling as a response to enduringly competing institutional logics. Academy of Management Journal, 56(4), 972-1001.

Pfeffer, J., \& Leblebici, H. (1973). Executive recruitment and the development of interfirm organizations. Administrative Science Quarterly, 18, 449-461.

Pfeffer, J., \& Salancik, G. (1978). The external control of organizations. New York, NY: Harper and Row.

Ragin, C. C. (1994). Introduction to qualitative comparative analysis. The Comparative Political Economy of the Welfare State, 299, 300-309.

Schoar, A., \& Zuo, L. (2011). Shaped by booms and busts: How the economy impacts CEO careers and management styles. Working Paper No. 17590. National Bureau of Economic Research.

Scott, W. R. (1995). Institutions and organizations. Thousand Oaks, CA: Sage.

Stinchcombe, A. L. (1965). Social structure and organizations. In J. G. March (Ed.), Handbook of organizations (pp.142-193). Chicago. IL: Rand McNally \& Co.

Strauss, A., \& Corbin (1998). Basics of qualitative research. Techniques and procedures for developing grounded theory. Thousand Oaks: Sage.

Suchman, M. C. (1995). Managing legitimacy: Strategic and institutional approaches. Academy of Management Review, 20(3), 571-610.

Sydow, J., Georg, S., \& Koch, J. (2009). Organizational path dependence: Opening the black box. Academy of Management Review, 34(4), 689-709.

Taylor, R. N. (1984). Behavioral decision making. Glenview, IL: Scott Foresman \& Co.

Thornton, P. H. (2004). Markets from culture: Institutional logics and organizational decisions in higher education publishing. Stanford, CA: Stanford University Press.

Thornton, P. H., \& Ocasio, W. (2008). Institutional logics. In R. Greenwood, C. Oliver, R. Suddaby, \& K. Sahlin-Andresson (Eds.), The Sage Handbook of organizational Institutionalism (pp. 99-129). London: Sage.

Thornton, P. H., Ocasio, W., \& Lounsbury, M. (2012). The institutional logics perspective: A new approach to culture, structure and process. Cambridge: Oxford University Press.

Tolbert, P. S., David, R. J., \& Sine, W. D. (2011). Studying choice and change: The intersection of institutional theory and entrepreneurship research. Organization Science, 22(5), $1332-1344$.

Tushman, M. L., \& Anderson, P. (1986). Technological discontinuities and organizational environments. Administrative Science Quarterly, 31(3), 439-465.

Zuckerman, E. W. (1999). The categorical imperative: Securities analysts and the illegitimacy discount. American. Journal of Sociology, 104(5), 1398-1438. 